\title{
The effects of different types of written corrective feedbacks on students' texting mistakes
}

\author{
Hasan Güner Berkant ${ }^{\mathrm{a}, 1,{ }^{*}}$, Nuriye Batmaz Derer ${ }^{\mathrm{b}, 2}$, Ozgur Kursad Derer ${ }^{\mathrm{b}, 3}$ \\ ${ }^{a}$ Bozok University, Medrese Mahallesi Adnan Menderes Bulvarı, Atatürk Yolu 7. Km D:118, 66200 Azizli/Yozgat Merkez/Yozgat, Turkey

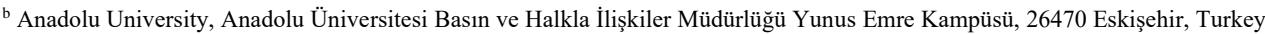 \\ ${ }^{1}$ hgberkant@gmail.com*; ${ }^{2}$ nurderer@windowslive.com; ${ }^{3}$ ok.derer@outlook.com.tr \\ * corresponding author
}

ARTICLE INFO

\section{Article history}

Received 23 November 2020

Revised 08 December 2020

Accepted 21 December 2020

\section{Keywords}

English lesson

writing activities

feedback

written corrective feedback

texting mistakes

\section{ABSTRACT}

The main purpose of this research was to investigate the effects of different types of written corrective feedback on students' texting mistakes in English lessons. In the study, a mixed model including quantitative and qualitative methods was engaged. Two-factor ANOVA was used for mixed measurements to test the significance of the difference between the error numbers of the three types of feedback except direct feedback. The qualitative data of the study were collected by examining the texts and the interviews about the effect of the four feedbacks were made with the students. Content analysis and descriptive analysis were performed. At the end of the study, in the quantitative findings obtained, the most effective type of feedback is the underlined feedback. As for the qualitative findings obtained from the students' opinions, the feedback type in which the error is coded and the information is given is the most effective type.

This is an open access article under the CC-BY-SA license.

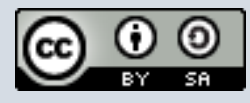

\section{Introduction}

The concept of feedback has many definitions in the literature. In these definitions, it is emphasized that it should inform the learner about whether he/she has behaved in accordance with the aims of education or whether he/she has acquired the target behaviors (Dysthe, 2007; Hattie \& Timperley, 2007; Joyce, Weil \& Calhoun, 2000). Feedback plays an essential role in students' achievement and learning (Carless, Salter, Yang \& Lam, 2011; Ellery, 2008; Ellis, Sheen, Murakami \& Takashima, 2008; Higgins, Hartley \& Skelton, 2010; Nakata, 2015; Nicol \& Macfarlane-Dick, 2006; Sendziuk, 2010; Shute, 2008). This role depends on several missions of feedback such as informing pupils about their work to come through the learning objectives along with for reinforcing and motivating their learning performance (Nelson \& Schunn, 2009).

Second language (L2) learning is a creative and developmental process in which student produces oral and written expressions in a foreign language. Students' L2 output is based on the rules of a language system they internalize (Hendrickson, 1980). L2 learning can also be defined as "developing knowledge about L2 and using it correctly" (Bitchener \& Storch, 2016). If students understand the rules and their usage well, they are expected to produce an L2 output that is grammatically and semantically appropriate. However, if students' hypotheses about language rule are sometimes incorrect, they can probably produce some false statements (Hendrickson, 1980).

\subsection{Written Corrective Feedback}

In the early days of foreign language learning, writing was applied solely to focus on students' grammar and vocabulary, and therefore errors were taken seriously (Brown, 2007; Ferris, 2010 Ferris \& Hedgcock, 2005). In accordance with Boughey (1997), writing has a great importance in 
second language learning just as other skills and students cannot acquire writing naturally, however, they learn it through formal instruction. It is a communication design that we need in any kind of fields, like self-expression and speech. The writing, which has developed in an actual way; it is like a channel for conveying emotions, thoughts, designs, and wishes to the clients. To reach messages in a correct way, this channel must be flawless, for example the text should be readable and understandable (Karatay, 2011). While writing, it is prevalent to make errors for learners. As Brown (2000) states that learners inevitably make mistakes while acquiring writing skills and then they benefit from miscellaneous forms of feedback on their errors and this is where feedback becomes the focus.

Various terms have been used for the same phenomenon, just as written error correction, written error feedback, or written corrective feedback (WCF). WCF can commonly be depicted as "... a dictated response to a lingual mistake in the writing of a passage by an L2 student. It aims to revise misuse or to provide data about where the mistake revealed and / or the cause of the mistake and how it can be corrected" (Bitcehener \& Storch, 2016). Teachers and researchers often have a strong belief that WCF is critical for improving their writing. Not only that, error correction is also the key contributing to student success in second language learning (Ellis, 2009). Correcting students' mistakes and providing students with feedback have become two of the routines and norms in discovering students' potential in acquiring language.

\subsection{Types of Feedback}

WCF is an accepted instructional strategy, considered essential and inalienable by lots of teachers to assist foreign language learners enhance their writing capability (Ferris, 2010). A serious number of investigation has studied the capability of corrective feedback in writing, and many researchers have identified positive and important effects of WCF (Aseeri, 2019; Atmaca, 2016; Ferris, 2003, 2004; Kang \& Han, 2015; Lee, 2019; Rahimi, 2009). Ellis (2009) has developed a categorization of teacher choices for correcting students' lexical mistakes in their written works. Her typology includes six essential strategies for implementing WCF, direct corrective feedback, indirect corrective feedback, metalinguistic corrective feedback, focused versus unfocused corrective feedback, electronic feedback, and reformulation.

In direct corrective feedback the teacher provides the learners with the correct form of knowledge. Ferris (2011) indicates that this may take various forms taking out an unessential word, phrase, or morpheme, inserting a missing word or morpheme, and writing the correct form above or near to the inaccurate form. Indirect corrective feedback suggests informing the learner about his/her texting mistakes without correction. That can be by highlighting the mistakes or using indicators to reveal the carelessness of learners or by placing a cross in the margin next to the text line consisting of the mistake. Underlined feedback was used by this way in present study. Metalinguistic corrective feedback consists of providing students with some form of precise remarks referring to the nature of the errors. The definitive comment may take two patterns. Probably the most prevalent is the usage of "error codes". These include abridged labels for various types of errors. The labels may be written on the part of the error in the passage or in the margin. In present study, coded feedback was used by this way.

In focused versus unfocused corrective feedback, teachers may reject to correct all errors of the learners when the corrective feedback is unfocused. Rather, they can pick peculiar mistake types for rectification. Dealing with correction is presumably more challenging in unfocused corrective feedback, because the student is compulsory to attend to several of errors and this is improbable to be able to display much on each mistake. Uncoded feedback was used in this context during the study. In electronic feedback, wide-ranging bulk of written English may be utilized to administer students with compensation in their writing. This support may be reached along computer programs as pupils note, or it may be promoted as a type of feedback. Whereas reformulation focuses on providing students with a source that they may utilize to revise their errors but places the liability for the last judgement about whether and how to revise on the learners themselves.

Lots of researches have been carried out whether WCF is instructive or not. In their study, Radecki and Swales (1988) studied the attitudes of 59 students attending to four English as a second language (ESL) oriented classes and got their ideas on the efficiency of different kinds of comments, the extension of teacher markings, responsibility in error marking and correction, and revision. Ferris and Roberts (2001) searched 72 university ESL students' various capacities to self-edit their 
passages across feedback conditions: coded, underlined and no feedback. Chandler (2003) examined if error correction progressed accuracy in student writing or not. Bitchener, Young and Cameron (2005) investigated to what degree the sort of corrective feedback on linguistic failures determined accuracy performance in new pieces of writing. Sheen (2007) investigated the miscellaneous effects of two kinds of WCF and the degree to which lingual analytic competence mediates the effects of feedbacks on the acquisition of articles. Ellis and et al. (2008) searched the diversity in the effect of focused and unfocused corrective feedbacks. In his study Ergünay (2008) investigated whether WCF creates any progress on learners' written accuracy or not. He also studied the various effects of direct and indirect written feedbacks on pupils' written accuracy and examined the permanent effects of distinctive written corrective feedback. Bitchener and Knoch (2009) had the purpose to discover if there was a divergent effect on accuracy for three different direct WCF options over a six-month period. Sheen, Wright and Moldawa (2009) investigated whether direct focused feedback, direct unfocused feedback and writing practice alone caused peculiar effects on the proper use of grammatical forms by ESL learner. Bitchener and Knoch (2010) searched the extent to which written corrective feedback may support advanced L2 learners. Hartshorn et al. (2010) tried to provide a brief explanation for WCF and to inquiry its effectiveness in one specific ESL learning context. Van Beuningen, De Jong and Kuiken (2012) investigated the effect of direct and indirect corrective feedback on second language learners' written accuracy. Kang and Han (2015) examined whether WCF aid to enhance the grammatical accuracy of second language writing or not. In her study Atmaca (2016) aimed to reveal the similarities and differences among students' and teachers' awareness about WCF in an EFL (English as a Foreign Language) context. Al-Hazzani and Altalhab (2018) examined the effect of teachers' WCF on female Saudi EFL pupils' written articles and to what degree it affected students' written grammatical and lingual accuracy. Köksal, Özdemir, Tercan, Gün and Bilgin (2018) investigated EFL teachers' opinions of WCF and the relationship between their WCF priorities and self-efficacy beliefs. Aseeri (2019) aimed to address the extent to which faculty members and students at the department of English language at Najran University practiced by using the ways of WCF. Kim and Bowles (2019) contrasted how second language learners practiced two kinds of written feedback: reformulation and direct correction. Lee (2019) searched the amount of feedback types teachers gave to students. Şakrak-Ekin and Balçıanlı (2019) investigated EFL instructors' beliefs about WCF.

Different from these related studies mentioned above, in this study the effects of different types of WCFs on the number of students' texting mistakes in English lessons were investigated by using both qualitative and quantitative data. In this context, the problem of the study can be defined as "What are the effects of different types of WCFs on the number of students' texting mistakes in English lessons?"

\subsection{Purpose of the Study}

The main purpose of this research is to investigate the effects of different types of WCFs on the number of students' texting mistakes in English lessons. In accordance with this main purpose, answers are searched for the following questions:

1. Is there a meaningful difference between the underlined and coded feedbacks given to the texts in terms of reducing students' mistakes?

2. Is there a meaningful difference between the underlined and uncoded feedback given to the texts in terms of reducing students' mistakes?

3. Is there a meaningful difference between the coded and uncoded feedback given to the texts in terms of reducing student mistakes?

4. What are the mistakes that students make in their writing work?

5. What are the opinions of students on the effects of WCF?

\section{Research Method}

In this section, information about the model, study group, procedure, data collection tool, data collection process and analysis are given. 


\subsection{Model of the Study}

This study employed mixed model, which is indicated as a research model that contains collecting and analyzing together or sequentially the qualitative and quantitative data in the same research (Creswell, Plano Clark, Gutmann \& Hanson, 2003). One-group pretest-posttest design was utilized in the research. It is one of the quasi-experimental designs, because the pariticipants weren't assigned randomly and a comparison/control group wasn't used (Privitera \& Ahlgrim-Delzell, 2019). Quasi-experimental research designs pursue if there is a causal relationship amidst independent and dependent variables (Loewen \& Plonsky, 2016). In the present study, three types of WCF (underlined, coded, uncoded) were used as independent variable, students' texting mistakes were determined as independent variable in one-group pretest-posttest design. The qualitative data of the study were collected via the interviews with the pupils about the effect of the four feedbacks at the end of the experimental process. Also, document investigation was used to see what kind of errors there were in the texts students wrote. Both interview and document investigation are types of qualitative research models and may be used together in the same research to enhance the reliability of data (Yildırım \& Şimşek, 2018). On the other hand, the quantitative dimension of the study consists of the numbers of written mistakes determined from the students' texts both before and after the application of three types of feedbacks in one-group design.

\subsection{Study Group}

The research was realized with 27 students aged 13-14 from eight grades in a secondary school in Kahramanmaraş City Elbistan District. Because the study was carried out in a school in which two of the researchers work, the convenience sampling model was used while determining the study group. Convenience sample is a kind of purposeful sampling model by which the study group is determined from a group of people providing a practical contact or reach (Yıldırım \& Şimşek, 2018).

\subsection{Procedure}

Different topics were determined for each type of feedback from the eighth grade English curriculum [Ministry of National Education (MNE), 2013]. Later, students were asked to write texts about these topics. The feedbacks were applied to the students' texts and the number of errors was noted. In the underlined feedback, the whole sentence including the wrong word was drawn. In the coded feedback, only the error type was written on the underscored mistakes by using some codes including initials of error type (i.e. grammar mistake-GM). The uncoded feedback was done by only underlining the incorrect word. Finally, the direct feedback was done by writing the correct form at the bottom of the wrong word. Because the direct feedback clearly indicated the answer key, except for the texts including direct feedback, the texts in which underlined, coded, and uncoded feedbacks given were rewritten and corrected by the students. Later, these texts were distributed to the students and they were asked to write again according to the feedback given. The rewritten texts were collected from the students once again, the errors were checked and the error numbers were noted.

\subsection{Data Collection Tool}

The texts which were given feedbacks and written by the students were used as data collection tool. The students were asked to write four different texts about subjects chosen from the eighth grade English curriculum (MNE, 2013). The selected subjects were related with "Friendship, Teen Life, Cooking, Communication".

\subsection{Data Collection Processes and Analysis}

Both the qualitative and quantitative data were collected from the texts students wrote. A part of qualitative data was collected by interviews made with students of the study group about the effects of feedbacks on their learning. The other part of qualitative data was collected by examining the passages drafted by the students before and after the feedback application. In the analysis of qualitative data, content analysis and descriptive analysis methods were used. Interview forms were analyzed by content analysis technique. Content analysis is the logical arrangement of basically similar data by reaching certain codes and themes and the interpretation of these data in an understandable way (Yıldırım \& Şimşek, 2018). Descriptive analysis is a technique in which the data are summarized and interpreted according to previously determined themes, direct quotations are frequently used to reflect the opinions of the interviewed individuals in a striking way, and the 
results obtained are interpreted within the framework of cause-effect relations (Yıldırım \& Şimşek, 2018).

Miles and Huberman's (1994) reliability formula was used to test the reliability of the interview data collected from students. Two researchers independently coded the answers and then their codes were compared by utilizing this formula. The researchers came to agreement in 23 codes while in 2 codes they disagreed among the 23 codes. When these numbers were replaced in the formula, the reliability value was determined as .91 . This value indicates the reliability of interview data, because the minimum value of reliability is expected to be at least .80 (Miles \& Huberman, 1994; Patton, 2002).

The quantitative data were collected from one-group treatment before and after the feedback application by counting the numbers of texting mistakes which were indicated from the students' texts. Two-way ANOVA for mixed measures were used in order to test the significance of the differences between the numbers of texting mistakes before and after the application according to the type of feedback.

\section{Findings and Discussion}

Quantitative and qualitative findings of the research are presented below.

\subsection{Quantitative Findings}

Findings of descriptive statistics of error numbers related to underlined and coded feedbacks are presented in Table 1.

Table 1. Descriptive Statistics of Error Numbers Related to Underlined and Coded Feedbacks

\begin{tabular}{lcccccc}
\hline Feedback Type & \multicolumn{3}{c}{ Before Feedback } & \multicolumn{3}{c}{ After Feedback } \\
\cline { 2 - 7 } & $\mathrm{N}$ & $\mathrm{X}$ & $\mathrm{S}$ & $\mathrm{N}$ & $\mathrm{X}$ & $\mathrm{S}$ \\
\cline { 3 - 7 } Underlined & 27 & 11.40 & 4.55 & 27 & 4.22 & 2.84 \\
Coded & 27 & 5.25 & 3.89 & 27 & 2.74 & 2.89
\end{tabular}

As shown in Table 1, the average of the error numbers before giving underlined feedback was 11.40, while it was 4.22 after the feedback. For the students given coded feedback, the error numbers averaged 5.25 before the feedback and 2.74 after the feedback. Accordingly, it can be stated that error numbers of students who were given both underlined and coded feedbacks decreased. Findings of two-factor ANOVA results regarding the error numbers related to underlined and coded feedbacks are presented in Table 2.

Table 2. Two-Factor ANOVA Results Regarding Underlined and Coded Feedbacks

\begin{tabular}{|c|c|c|c|c|c|}
\hline Source of Variance & Sum of Squares & sd & Mean Square & F & $\mathrm{p}$ \\
\hline Between subjects & 1660.06 & 53 & & & \\
\hline Group (Underlined-Coded) & 392.92 & 1 & 392.92 & 154.66 & .000 \\
\hline Error & 1267.14 & 52 & 24.36 & & \\
\hline Within Subjects & 878.99 & 54 & & & \\
\hline $\begin{array}{l}\text { Measurement } \\
\text { (Before feedback-After feedback) }\end{array}$ & 635.59 & 1 & 635.59 & 342.82 & .000 \\
\hline Group*Measurement & 147.00 & 1 & 147.00 & 79.28 & $.000^{*}$ \\
\hline Error & 96.40 & 52 & 1.85 & & \\
\hline Total & 2539.05 & 107 & & & \\
\hline
\end{tabular}


As seen in Table 2, the common effects of the repeated measures factors on the error numbers are meaningful when the error numbers of the students who were applied two different feedbacks differ significantly after the experiment, that is, in different transaction groups, $F(1,52)=79.28, \mathrm{p}<.05$. This finding suggests that underlined and coded feedbacks have different effects on students' error numbers. It is understood that students who were given underlined feedback after the experiment are more effective in reducing the number of mistakes compared to coded feedback.

Findings of descriptive statistics of error numbers related to underlined and uncoded feedbacks are presented in Table 3.

Table 3. Descriptive Statistics of Error Numbers Related to Underlined and Uncoded Feedbacks

\begin{tabular}{ccccccc}
\hline \multirow{2}{*}{ Feedback Type } & \multicolumn{3}{c}{ Before Feedback } & \multicolumn{3}{c}{ After Feedback } \\
\cline { 2 - 7 } & $\mathrm{N}$ & $\mathrm{X}$ & $\mathrm{S}$ & $\mathrm{N}$ & $\mathrm{X}$ & $\mathrm{S}$ \\
\hline Underlined & 27 & 11.40 & 4.55 & 27 & 4.22 & 2.84 \\
Uncoded & 27 & 8.14 & 4.02 & 27 & 4.14 & 3.35 \\
\hline
\end{tabular}

As shown in Table 3, the average of the error numbers before the feedback of the students who were given underlined feedback was 11.40 while it was 4.22 after the feedback. In the students who were given the uncoded feedback, the error numbers averaged 8.14 before the feedback and 4.14 after the feedback. Accordingly, it can be stated that there is a decrease in the error numbers of the students who are given both underlined and uncoded feedbacks.

Findings of two-factor ANOVA results regarding underlined and uncoded feedbacks are presented in Table 4.

Table 4. Two-Factor ANOVA Results Regarding Underlined and Uncoded Feedbacks

\begin{tabular}{|c|c|c|c|c|c|}
\hline Source of Variance & Sum of Squares & Sd & Mean Square & $\mathrm{F}$ & $\mathbf{p}$ \\
\hline Between subjects & 1442.96 & 53 & & & \\
\hline Group (Underlined-Uncoded) & 75 & 1 & 75 & 2.85 & .097 \\
\hline Error & 1367.96 & 52 & 26.30 & & \\
\hline Within Subjects & 1010.99 & 54 & & & \\
\hline $\begin{array}{l}\text { Measurement } \\
\text { (Before feedback-After feedback) }\end{array}$ & 844.48 & 1 & 844.48 & 447.92 & .000 \\
\hline Group*Measurement & 68.48 & 1 & 68.48 & 36.32 & $.000^{\circ}$ \\
\hline Error & 98.03 & 52 & 1.88 & & \\
\hline Total & 2453.95 & 107 & & & \\
\hline
\end{tabular}

As seen in Table 4, the common effects of the repeated measures factors on the error numbers are meaningful when the error numbers of the students who were applied two different feedbacks differ significantly after the experiment, that is to say in the different transaction groups, $F(1,52)=36.32$, $\mathrm{p}<.001$. This finding suggests that underlined and uncoded feedbacks have different effects on students' failure to reduce their numbers. It is understood that students who were underlined after the experiment are more effective in reducing the number of mistakes compared to uncoded feedback.

Findings of descriptive statistics of error numbers related to coded and uncoded feedbacks are given in Table 5. 
Table 5. Descriptive Statistics of Error Numbers Related to Coded and Uncoded Feedbacks

\begin{tabular}{cccccccc}
\hline \multirow{2}{*}{ Feedback Type } & \multicolumn{3}{c}{ Before Feedback } & \multicolumn{3}{c}{ After Feedback } \\
\cline { 2 - 7 } & $\mathrm{N}$ & $\mathrm{X}$ & $\mathrm{S}$ & $\mathrm{N}$ & $\mathrm{X}$ & $\mathrm{S}$ \\
\hline Coded & 27 & 5.25 & 3.89 & 27 & 2.74 & 2.89 \\
Uncoded & 27 & 8.14 & 4.02 & 27 & 4.14 & 3.35 \\
\hline
\end{tabular}

As shown in Table 5, the average of the error numbers at the beginning of the coded feedbacked students was 5.25, and it was 2.74 after the feedback. In the students who were given the uncoded feedback, the error numbers averaged 8.14 before the feedback and 4.14 after the feedback. Accordingly, it can be stated that the error numbers of the students who were given both coded and uncoded feedbacks decreased. 6.

Findings of two-way ANOVA results regarding coded and uncoded feedbacks are given in Table

Table 6. Two-Way ANOVA Results Regarding Coded and Uncoded Feedbacks

\begin{tabular}{|c|c|c|c|c|c|}
\hline Source of Variance & Sum of Squares & sd & Mean Square & $\mathbf{F}$ & $\mathrm{p}$ \\
\hline Between subjects & 1442.96 & 53 & & & \\
\hline Group (Underlined-Uncoded) & 75 & 1 & 75 & 2.85 & .097 \\
\hline Error & 1367.96 & 52 & 26.30 & & \\
\hline Within Subjects & 1010.99 & 54 & & & \\
\hline $\begin{array}{l}\text { Measurement } \\
\text { (Before feedback-After feedback) }\end{array}$ & 844.48 & 1 & 844.48 & 447.92 & .000 \\
\hline Group*Measurement & 68.48 & 1 & 68.48 & 36.32 & $.000^{*}$ \\
\hline Error & 98.03 & 52 & 1.88 & & \\
\hline Total & 2453.95 & 107 & & & \\
\hline
\end{tabular}

As seen in Table 6, the common effects of the repeated measures factors on the error numbers are meaningful when the error numbers of the students who were applied two different feedbacks differ significantly after the experiment, that is to say in different transaction groups, $\mathrm{F}(1,52)=36.32$, $\mathrm{p}<$ .001 . This finding suggests that coded and uncoded feedbacks have different effects on reducing the error numbers of students. It is understood that after the experiment the students who were given uncoded feedback due to the decrease in the number of mistakes are more effective in decreasing the number of mistakes compared to coded feedback.

\subsection{Qualitative Findings}

Qualitative findings of the document investigation and interviews are presented below.

\subsection{Findings of Document Investigation}

There were grammatical mistakes such as not choosing the appropriate English verb tense for conveying an idea or not using it in correct form and subject-verb agreement:

S1: "I did go shopping with my best friend yesterday."

S17: "She prefer go for a walk to stay at home"

There were spelling mistakes such as incorrect homophones (words with the same pronunciation, such as "right", "rite" and "write"), writing the word in a wrong way.

S3: "I had a terrible day with my friend yesterday. We really had fun." (terrific) 
S12: "There are tree kinds of communication tools that we use mostly in our houses" (three)

Apostrophe errors took place in students' writing works.

S9: "My mums close friend texts messages to communicate" (mum’s)

\subsection{Findings of Students' Opinions about the Effects of Different Types of WCFs on Students' Texting Mistakes}

Students' answers to the question whether writing activities improve their English are given in Table 7 .

Table 7. Contribution of Writing Activities to Students' English

\begin{tabular}{lc}
\hline \multicolumn{1}{c}{ Codes } & f \\
\hline Entertaining & 11 \\
Useful & 9 \\
Instructive & 8 \\
Boring & 7 \\
Time-consuming & 5 \\
\hline
\end{tabular}

As seen in Table 7, less than half of the students (11/27) thought that writing activities were entertaining. Besides, some of the students found writing activities useful (9/27) and instructive $(8 / 27)$ However, as negative opinions, some of the students found the activities boring (7/27) and time consuming (5/27). Some of the students' views about contributions of writing activities are as follows:

S2: "Why should I like to write in the foreign language? I'm still learning, while I don't like writing in my own mother tongue. As I can talk, I don't need to write. It is both boring and time-consuming."

S13: "I love writing essays or stories in Turkish lessons. Because as I can't express myself while talking, I think I can express it very well by writing it. Writing is very important to me. I find writing fun, no matter in what language it is."

Students' answers to the question what activities and instruments help to improve their writing skills are given in Table 8.

Table 8. The Activities and Instruments that Help to Improve Students' Writing Skills

\begin{tabular}{lc}
\hline \multicolumn{1}{c}{ Codes } & f \\
\hline Dictionaries & 27 \\
Teachers' feedbacks & 23 \\
Grammar lessons & 22 \\
Reading activities & 16 \\
Listening to songs & 15 \\
Giving feedbacks to the friends & 13 \\
Keeping a diary & 9 \\
Watching movies & 7 \\
Translation works & 6 \\
\hline
\end{tabular}

As seen in Table 8, all of the students (27/27) thought that dictionaries were very useful in their writing works and they helped them improve their writing works. Most of the students declared that feedbacks from teachers (23/27) and grammar lessons (22/27) helped them improve their writing 
works. Few students put forward that watching movies (7/27) and working on translation (6/27) improved their writing skills. Some of the students' answers on this topic are as follows:

S4:"I think dictionaries help me a lot while writing. Because when I don't remember a word in English, I look up the dictionary to learn it. As I use a dictionary, I can remember the word more easily when I have to use it later again. So, dictionaries really help me while writing."

S15: "When I write something, it is really important to me to get feedbacks from my teachers. Because they tell me what mistakes I make and what word I used in a wrong way. When I learn that I don't make the same mistakes again."

Students' answers to the effectiveness of WCFs on learning English are given in Table 9.

Table 9. The Effectiveness of WCFs

\begin{tabular}{|c|c|}
\hline Codes & f \\
\hline Effective & 23 \\
\hline Not Effective & 4 \\
\hline
\end{tabular}

As seen in Table 9, most of the students (23/27) found WCFs effective on learning English 23 of 27 students thought that were effective, however a few students (4/27) declared the ineffectiveness of these feedbacks. Some of the students' views about the effectiveness of feedbacks are as follows:

S5: "Getting WCFs from my teacher was really effective for me. As I am learning a new language, it is very normal for me to make mistakes. But sometimes I do not know whether I make mistakes or I do not understand why I make mistakes. When I get WCFs from my teachers, I get sure about my mistake and I try not to do the same mistakes again."

S19: "It was very effective. We wrote about four subjects and this was the first time I wrote so much in English. I saw that I could write because I did not have self-confidence. After getting WCFs from my teacher helped me get more self-confident. I learnt how to express myself by writing in a better way.

Students' answers about the most challenging issues in English writing activities are given in Table 10.

Table 10.

\begin{tabular}{lcc}
\hline \multicolumn{1}{c}{ Codes } & f \\
\cline { 2 - 2 } Use/Expression of words & 22 \\
Lack of confidence & 20 \\
Fear of failure & 18
\end{tabular}

As seen in Table 10, most of the students (22/27) accepted that they did not know the way how to use or express words in second language. Also, many students (20/27) declared that they were lack of confidence during English writing activities and 18 of 27 students pointed out that they were afraid of making mistakes or being unsuccessful. Some of the students' opinions about these challenging issues are as follows:

S9: "I don't like writing in my own language so while writing in a foreign language I do not feel myself confident. I get afraid of making mistakes. Teachers help me a lot by giving feedback but I hate making mistakes. I feel ashamed."

S20:"I am afraid of being unsuccessful. I love my English teacher so much so I want her to see me as a successful student. When my teacher wants me to write something, I want it to be perfect." 
Students' answers about their most preferred WCF types are given in Table 11.

Table 11. The Most Preferred WCF Types

\begin{tabular}{lcc}
\hline \multicolumn{1}{c}{ Codes } & f \\
\hline Coded feedback & 10 \\
Underlined feedback & 8 \\
Direct feedback & 6 \\
Uncoded feedback & 3 \\
\hline
\end{tabular}

As seen in Table 11, students pointed out that among the feedback types they mostly found coded feedback more effective. Secondly underlined feedback, third direct feedback, and lastly uncoded feedback were more declared as effective feedbacks respectively. Some of the students' views about the sequence of feedback efficiency are as follows:

S7: "I think coded feedback was the most effective one. Because my teacher just gave me codes and I tried to find the mistake. I liked searching what my mistake was and I think that was the best way for my learning."

S17: "I think the best feedback type was direct one. I want to learn my mistake and I do not want to do it again. When my teacher tells me about my mistake, I do not need to search it by myself. If so, it would be too time consuming.

It was concluded from the quantitative findings that the most effective feedback type was "underlined" on decreasing the number of students' texting mistakes. The second most effective feedback was "uncoded", and the least effective one was "coded". As for the results of qualitative findings from the students' views, "coded" was the most effective feedback, "underlined" was the second most effective one, "direct" was the third most effective one and the least effective one was "uncoded". Because the quantitative findings showed that the most effective feedback type was "underlined" and the qualitative findings declared that the most effective one was "coded", a contradiction was determined between the students' perceptions and the statistical results about the effectiveness of feedback types. Document investigation showed that students had grammatical, spelling, and apostrophe mistakes during the writing activities.

Although limited number of students evaluated the writing activities including WCFs boring and ineffective, most of the students declared that these activities were entertaining and useful for improving their writing skills in English. Students' ideas indicated that dictionaries, teacher's feedbacks, grammar-based lessons, and reading activities were the most useful tools to improve their writing skills. According to students' views, most of them didn't have enough self-confidence and had a fear of failure in English writing activities because they didn't have enough vocabulary knowledge. Also, they didn't know how to use or express the words correctly.

The research results revealed that in writing activities, the usage of WCFs was effective. Similar to the results of this research, Al-Hazzani and Altalhab's (2018) study showed that WCF had positive effects on students' writing achievements and helped develop learners' skills. It also revealed that grammatical and lexical accuracy could be improved through the regular giving of WCF. Their studies offered positive support for the practice of WCF and added to the growing body of evidence investigating and indicating the influence of teachers' WCF on improving EFL learners' writing achievements and making fewer errors. Based on this result, corrective feedbacks used in English writing classroom can be instructive and supportive for students to participate in writing activities so students can be willing to perform the writing activities. Similarly, Ferris and Roberts (2001) found that groups who received feedback significantly surpassed the no-feedback group. Ergünay (2008) concluded that the experimental groups who received WCF significantly outperformed the control group in which any WCF wasn't received in both short and long term. Chandler's (2003) study demonstrated that the accuracy of students' writings was improved significantly by feedbacks. Bitchener and Knoch (2010) came upon that all three analysis groups in 
which three sorts of feedback were used surpassed the control group receiving no feedback due to the post-test scores.

Kang and Han (2015) resulted that WCF could lead to greater grammatical accuracy in second language writing activities. Lee (2019) indicated that, the usage of corrective feedbacks aided students' writing development and ensured more active involvement. Hartshorn and et al. (2010) stated that a systematic approach including WCF could have a positive effect on the accuracy of ESL writing. Van Beuningen and et al. (2011) showed that comprehensive corrective feedback was an efficient means of improving learners' accuracy. They found that pupils whose errors were corrected comprehensively made fewer errors in new pieces of writing than learners who did not get feedbacks. When students receive feedback, they can revise their paragraphs and this situation may allow them to focus on previous mistakes they have made.

Furthermore, in this study students declared that the most effective feedback types were underlined and coded on decreasing the number of their texting mistakes. Similar to this result, Chandler (2003) stated not all error correction methods had the same effect in increasing accuracy. As there are different types of students, various learning styles and language characteristics, it can be very common to have differences in the types of feedback. Kim and Bowles (2019) stated that there might not be a one-size-fits-all answer for WCF but that various mistakes responded to feedback variously. In a similar way Aseeri (2019) concluded that correcting students' errors by coding the exact error in the text without giving them the correct answer was the least used way from students' viewpoints. At this point, as revealing mistakes through codes will make students struggle with writing activities, it may be a little more challenging for them.

Contrary to this study's result, in Ergünay's (2008) research direct corrective feedback was declared as the most useful. Also, Bitchener et al. (2005) concluded that indirect feedback was more effective than direct feedback in helping learners improve the accuracy of their writing. Bitchener and Knoch (2010) detected no significant dissimilarity among the three treatment groups on the immediate post-test piece of writing, suggesting that any one of three types of WCF could be used by teachers and still have the same positive effect. Various feedback forms promoted distinctive sense of processing by all of L2 learners of English. The results also showed a significant relationship among error type and depth of processing. The effectiveness of different sorts of feedbacks in the mentioned studies may be due to various learning and teaching styles.

\section{Conclusion}

This study aimed to investigate the effects of different types of WCF on students' texting mistakes in English lessons. Four different texts in the English curriculum were studied and each student's number of errors in these texts was determined and four types of feedback were given to the texts. It was found that in the quantitative findings obtained, the most effective type of feedback is the underlined feedback in which the whole sentence with error is underlined, the second most effective type of feedback is the uncoded type of feedback where only the word error is underlined, and the least effective one is the coded feedback in which error is coded. It was concluded that it is the type of feedback to which the information is given. As for the qualitative findings obtained from the students' opinions, the feedback type in which the error is coded and the information is given is the most effective type of feedback, the second most effective type of feedback is the one in which the whole sentence with error is underlined, the least effective type of feedback is uncoded feedback, which is the type of feedback where only the wrong word is underlined. Based on the results of this study, the following suggestions are put forward for researchers:

This study was limited to eight grade students' writing activities including feedbacks in English. Further research can be conducted in other grade levels via speaking, listening, and reading activities. In this study coded, uncoded, direct, and underlined feedback types were studied. With the purpose of introducing some profound vision to the literature, researches comprising the use of other types of WCFs such as metalinguistic, focused, unfocused, electronic feedbacks may be carried out. 


\section{REFERENCES}

Al-Hazzani, N., \& Altalhab, S. (2018). Can explicit WCF develop grammatical and lexical accuracy of Saudi EFL learners? International Journal of Education and Literacy Studies, 6(4), 16-24. http://dx.doi.org/10.7575/aiac.ijels.v.6n.4p.16

Aseeri, F. M. (2019). WCF as practiced by instructors of writing in English at Najran University. Journal of Education and Learning, 8(3), 12-12. http://dx.doi.org/10.5539/jel.v8n3p112

Atmaca, Ç. (2016). Contrasting perceptions of students and teachers: WCF. Journal of Language and $\begin{array}{lllll}\text { Linguistic } & \text { Studies, } & \text { 12(2), } & \text { Retrieved }\end{array}$ https://dergipark.org.tr/tr/pub/jlls/issue/36115/405548

Bitchener, J., \& Knoch, U. (2009). The relative effectiveness of different types of direct WCF. System, 37(2), 322-329. http://dx.doi.org/10.1016/j.system.2008.12.006

Bitchener, J., \& Knoch, U. (2010). Raising the linguistic accuracy level of advanced L2 writers with WCF. Journal of Second Language Writing, 19(4), 207-217. http://dx.doi.org/10.1016/j.jslw.2010.10.002

Bitchener, J., \& Storch, N. (2016). Written corrective feedback for L2 development. Bristol: Multilingual Matters.

Bitchener, J., Young, S., \& Cameron, D. (2005). The effect of different types of corrective feedback on English as a second language (ESL) student writing. Journal of Second Language Writing, 14(3), 191-205. http://dx.doi.org/10.1016/j.jslw.2005.08.001

Boughey, C. (1997). Learning to write by writing to learn: A group- work approach. ELT Journal, 51(2), 126-134. http://dx.doi.org/10.1093/elt/51.2.126

Brown, D. H. (2000). Principles of language learning \& teaching. (4th ed.). Longman.

Brown, D. H. (2007). Principles of language learning and teaching. Longman.

Carless, D., Salter, D., Yang, M., \& Lam, J. (2011). Developing sustainable feedback practices. Studies in Higher Education, 36(4), 395-407. http://dx.doi.org/10.1080/03075071003642449

Chandler, J. (2003). The efficacy of various kinds of error feedback for improvement in the accuracy and fluency of L2 student writing. Journal of Second Language Writing, 12(3), 267-296. http://dx.doi.org/10.1016/S1060-3743(03)00038-9

Creswell, J. W., Plano Clark, V. L., Gutmann, M. L., \& Hanson, W. E. (2003). Advanced mixed methods research design. In A. Tashakkori and C. Teddlie (Eds.), Handbook of mixed methods in the behavioral and social research (pp. 209-240). Sage.

Dysthe, O. (2007). How a reform affects writing in higher education. Studies in Higher Education, 32(2), 237-252. http://dx.doi.org/10.1080/03075070701267285

Ellery, K. (2008). Assessment for learning: A case study using feedback effectively in an essay-style test. Assessment and Evaluation in Higher Education, 33(4), 421-429. http://dx.doi.org/10.1080/02602930701562981

Ellis, R. (2009). A typology of WCF types. English Language Teaching Journal, 63(2), 97-107. http://dx.doi.org/10.1093/elt/ccn023

Ellis, R., Sheen, Y., Murakami, M., \& Takashima, H. (2008). The effects of focused and unfocused WCF in an English as a foreign language context. System, 36(3), 353-371. http://dx.doi.org/10.1016/j.system.2008.02.001

Ergünay, O. (2008). The effects of WCF on Turkish EFL learners' use of state verbs: An experimental study. Master Thesis. Eskişehir: Anadolu University, Institution of Educational Sciences.

Ferris, D. R. (2003). Response to student writing: Implications for second language students. Lawrence Erlbaum Associates.

Ferris, D. R. (2004). The "grammar correction" debate in L2 writing: Where are we, and where do we go from here? (and what do we do in the meantime...?). Journal of Second Language Writing, 13(1), 4962. http://dx.doi.org/10.1016/j.jslw.2004.04.005 
Ferris, D. R. (2010). Second language writing research and WCF in SLA. Studies in Second Language Acquisition 32(2), 181-201. http://dx.doi.org/10.1017/S0272263109990490

Ferris, D. R. (2011). Treatment of error in second language student writing (2nd ed.). The University of Michigan Press.

Ferris, D. \& Hedgcock, J. (2001). Teaching ESL composition: Purpose, process, and practice. TESOL Quarterly 35(1). http://dx.doi.org/10.1016/S0889-4906(00)00006-5

Ferris, D., \& Roberts, B. (2001). Error feedback in L2 writing classes. Journal of Second Language Writing, 1O(3), 161-184. https://doi.org/10.1016/s1060-3743(01)00039-x

Hartshorn, K. J., Evans, N. W., Merrill, P. F., Sudweeks, R. R., Strong-Krause, D., \& Anderson, N. J. (2010). Effects of dynamic corrective feedback on English as a second language (ESL) writing accuracy. TESOL Quarterly, 44(1), 84-109. https://doi.org/10.5054/tq.2010.213781

Hattie, J., \& Timperley, H. (2007). The power of feedback. Review of Educational Research, 77(1), 81-112. https://doi.org/10.3102/003465430298487

Hendrickson, M. (1980). The treatment of error in written work. Modern Language Journal, 64(2), 216-221. https://doi.org/10.2307/325306

Higgins, R., Hartley, P., \& Skelton, A. (2010). The conscientious consumer: Reconsidering the role of assessment feedback in student learning. Studies in Higher Education, 27(1), 53-64. https://doi.org/10.1080/03075070120099368

Joyce, B. R., Weil, M., \& Calhoun, E. (2000). Models of teaching (6th edition). Sixth edition. Allyn and Bacon.

Kang, E., \& Han, Z. (2015). The efficacy of WCF in improving 12 written accuracy: a meta-analysis. Modern Language Journal, 99(1), 1-18. https://doi.org/10.1111/modl.12189

Karatay, H. (2011). Süreç temelli yazma modelleri: Planlı yazma ve değerlendirme. M. Özbay (Ed.), Yazma eğitimi (21-43). Pegem.

Kim, H. R., \& Bowles, M. (2019). How deeply do second language learners process WCF? Insights gained from think-alouds. TESOL Quarterly: A Journal for Teachers of English to Speakers of Other Languages and of Standard English as a Second Dialect, 53(4), 913-938. https://doi.org/10.1002/tesq.522

Köksal, D., Özdemir, E., Tercan, G., Gün, S., \& Bilgin, E. (2018). The relationship between teachers' written feedback preferences, self-efficacy beliefs and burnout levels. Journal of Language and Linguistic Studies, 14(4), 316-327. Retrieved from https://dergipark.org.tr/tr/pub/jlls/issue/43366/528125

Lee, I. (2004). Error correction in L2 secondary writing classroom: The case of Hong Kong. Journal of Second Language Writing, 13(4), 285-312. https://doi.org/10.1016/j.jslw.2004.08.001

Lee, I. (2019). Teacher WCF: Less is more. Language Teaching, 52(4), 524-536. https://doi.org/10.1017/S0261444819000247

Loewen, S., \& Plonsky, L. (2016). An A-Z of applied linguistics research methods. Palgrave Macmillan.

Ministry of National Education (MNE). (2013). English Language Teaching Program (Primary and Secondary Schools Grades 2,3,4,5,6,7 and 8). Ankara: MEB Publications.

Miles, M, B., \& Huberman, A. M. (1994). Qualitative data analysis: An expanded sourcebook (2nd Ed.). Sage.

Nakata, T. (2015). Effects of feedback timing on second language vocabulary learning: Does delaying feedback increase learning? Language Teaching Research, 19(4), 416-434. https://doi.org/10.1177\%2F1362168814541721

Nelson, M. M., \& Schunn, C. D. (2009). The nature of feedback: How different types of peer feedback affect $\begin{array}{llll}\text { writing } & \text { performance. } & \text { Instructional 375-401. }\end{array}$ https://psycnet.apa.org/doi/10.1007/s11251-008-9053-x 
Nicol, D. C., \& Macfarlane-Dick, D. (2006). Formative assessment and self-regulated learning: a model and seven principles of good feedback practice. Studies in Higher Education, 31(2), 199-218. https://doi.org/10.1080/03075070600572090

Patton, M. Q. (2002). Qualitative research and evaluation methods (3rd Ed.). Sage.

Privitera, G. J., \& Ahlgrim-Delzell, L. (2019). Research methods for education. Sage.

Radecki, P. M., \& Swales, J. M. (1988). English as a second language (ESL) student reaction to written comments on their written work. System, 16(3), 355-365. http://dx.doi.org/10.1016/0346251X(88)90078-4

Rahimi, M. (2009). The role of teacher's corrective feedback in improving Iranian EFL learners' writing accuracy over time: Is learners' mother tongue relevant? Reading and Writing, 22(2), 219-243. http://dx.doi.org/10.1007/s11145-008-9139-5

Şakrak-Ekin, G., \& Balçıkanlı, C. (2019). WCF: EFL teachers' beliefs and practices. Reading Matrix: An International Online Journal, 19(1), 114-128.

Sendziuk, P. (2010). Sink or swim? Improving student learning through feedback and self-assessment. International Journal of Teaching and Learning in Higher Education, 22(3), 320-330.

Sheen, Y. (2007). The effect of focused WCF and language aptitude on english as a second language (ESL) learners' acquisition of articles. TESOL Quarterly, 41(2), 255-283. https://doi.org/10.1002/j.15457249.2007.tb00059.x

Sheen, Y., Wright, D., \& Moldawa, A. (2009). Differential effects of focused and unfocused written correction on the accurate use of grammatical forms by adult English as a second language (ESL) learner. System, 37(4), 556-569. https://doi.org/10.1016/j.system.2009.09.002

Shute, V. J. (2008). Focus on formative feedback. Review of Educational Research, 78(1), 153-189. https://doi.org/10.3102\%2F0034654307313795

Van Beuningen, C. G., De Jong, N. H., \& Kuiken, F. (2011). Evidence on the effectiveness of comprehensive error correction in second language writing. Language Learning, 62(1), 1-41. https://doi.org/10.1111/j.1467-9922.2011.00674.x

Yıldırım, A., \& Şimşek, H. (2018). Sosyal bilimlerde nitel araştırma yöntemleri. Ankara: Pegem Akademi. 